\title{
Patronage avoidance in James
}

\section{John S Kloppenborg Verbin}

Toronto

\begin{abstract}
James 2:1-13 takes the form of a rhetorical "elaboration on a theme" described in

Ps-Cicero's Rhetorica ad Herennium 2.18.28, and is directed not merely at the abstract issue of partiality or the issue of rich versus poor, but at the practice of patronage and its attendant effects on social interaction. James attacks the practice of patronage and reliance on the stereotypes of patronage as demeaning pseudo-friendship as well as the client, and contrasts this with true friendship from God.
\end{abstract}

\section{INTRODUCTION}

In third century CE Phocaea a woman named Tation, who is identified with both a patronym and a papponym, paid for the construction of an assembly hall and its

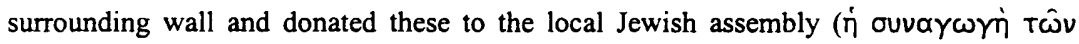

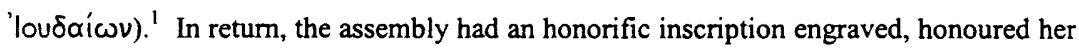
with a golden crown, and assigned to her the privilege of sitting in the front seat

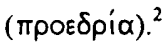

Such an acknowledgement of the largess and goodwill of a wealthy and distinguished person was quite unexceptional. Hundreds, even thousands, of honorific decrees inscribed on stone and metal tabulae are extant, attesting the benefactions of the wealthy

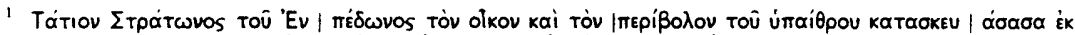

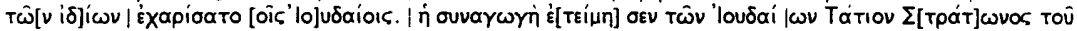

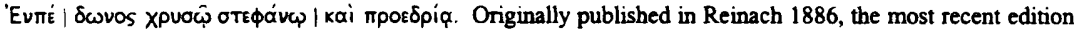
is found in Engelmann 1976, no 45. For earlier editions, see CIJ II no. 738; Lifshitz 1967, $21-22$ (no 13). In this paper I employ the epigraphical abbreviations proposed by Horsley and Lee 1994.

${ }^{2}$ Both the bestowal of a golden crown and the assigning of the privilege of the $\pi \rho \circ \delta \delta \rho i \alpha$ are conventional in civic honorific inscriptions, where the honoree is given the $\pi$ poв $\delta$ pia at the games. For example IMagnMai

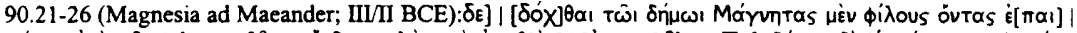

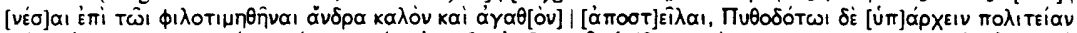

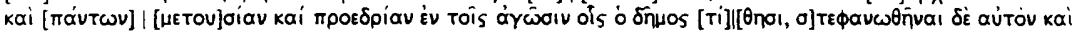

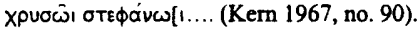


and the gratitude of their clients. Tation's act, and that of the assembly, illustrate the asymmetrical exchange of goods and services known as patronage, where the patron provided benefits, including goods, services, access to social networks, and protection, and the client was expected to make acknowledgement of those benefits through loyalty, attendance at the morning salutatio, and various other displays of gratitude. ${ }^{3}$ The only seemingly unusual aspect of Tation's case is that a woman is given the front seat in a prayer house. But this is only unusual if one assumes, against other evidence, that women played no special role in prayer houses of the early Roman period ${ }^{4}$ or, more generally, that women were not functionaries and honorees in other associations in Roman Asia. $^{5}$

The Letter of James also entertains the scenario of a distinguished man in the

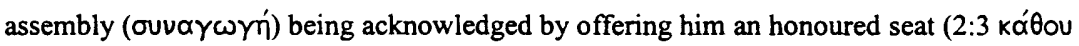
$\hat{\omega} \delta \varepsilon k \propto \lambda \hat{\omega} s$ ). But instead of commending the deferential treatment that most of his contemporaries would offer, virtually by reflex, James condemns it, and presents a complex argument concluding that such deference amounts to a violation of Torah (2:5-13).

This scene is invoked in the context of a pericope $(2: 1-13)$ that begins with an

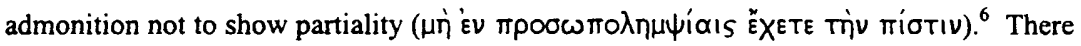
it serves to dramatize the admonition, since the deference shown the rich man is contrasted with the rather casual disregard of a poor man, who is simply told to stand

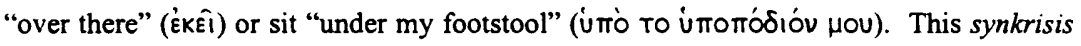
of rich and poor belongs in turn to a larger rhetoric in James which contrasts the transitory existence of the rich with the coming exaltation of the humble $(1: 9-10 ; 2: 5)$ and

3 Richard Saller's definition of patronage (which adapts that of Gellner) has become standard: Patronage "involves the reciprocal exchange of goods and services. Secondly, to distinguish it from a commercial transaction in the marketplace, the relationship must be a personal one of some duration. Thirdly, it must be asymmetrical, in the sense that the two parties are of unequal status and offer different kinds of goods and services in exchange - a quality which sets patronage off from friendship between equals" (Saller 1989, 49 [emphasis original]; Gellner 1977, 1). Millett $(1989,16)$ adds a fourth component to Saller's definition: "the relationship was conducted along lines largely determined by the party of superior status. It is this that opens up the way for the exploitation that is so common in patron-client relations."

4 For evidence of women's roles in prayer houses, see especially Brooten 1982; 1991; Cohen 1980, 23-29.

s On the evidence of women's public function in Asia, see Trebilco 1991, 113-26.

- The verb EXER is usually taken as an imperative rather than an indicative: Mayor 1910, 79; Ropes 1916, 186; Dibelius 1976, $126 \mathrm{n}$. 9. Maynard-Reid $(1987,49)$ takes $\mu \eta \dot{~ E x}$ हTe to be an interrogative. 
in which the author aligns himself and his implied readers against the rich, who are accused of oppressing the poor in various ways (2:6-7; 5:1-6). Most commentators on James 2:1-13 have concluded that the pericope concerns the problem of partiality, conceived rather generally, or the negotiation of the relation of rich and poor, either within a Christian group or between a poor community and wealthy outsiders.

This pericope has been seen as a key site for ascertaining the social location of James and of the communities addressed by the letter. ${ }^{7}$ Commentators are divided on several exegetical issues: first, whether the scene is set at a Sabbath gathering ${ }^{8}$ or, treating

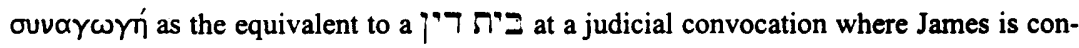
cerned that a rich litigant not automatically be preferred to a poor one'; second, whether the two persons are imagined to be members of the assembly or visitors ${ }^{10}$; and finally, whether the description of the rich man - the mention of the gold ring and the fine clothing - is intended to signify his equestrian status. ${ }^{11}$ These decisions, however, depend on a prior one. Ever since Martin Dibelius' 1921 commentary on James and his excursus on the James' use of examples, doubts linger as to whether James' examples are not utterly hypothetical, telling us nothing at all about the actual situation of his addres-

\footnotetext{
${ }^{7}$ See in general, Popkes 1986, 53-63; Burchard 1980, 315-28.

${ }^{8}$ Mayor 1910, 82-83; Ropes 1916, 185; Dibelius 1976, 133-35; Moffatt 1928, 32; Windisch 1930, 14; Mitton 1966, 83; Laws 1980, 101-102; Schnider 1987, 57; Hoppe 1989, 52; Trocmé 1964, 662.

9 Ward 1969, 87-97, esp. 96-97; Davids 1982, 108, 109-10; Martin 1988, 57-58; Wachob 1993, 166-68.

${ }^{10}$ Members: Weiss 1904, 5; Chaine 1927, 42 ("sans doute"); Ward 1969, 94; Davids (1982, 109) thinks the two are new converts but strangers to the judicial assembly and hence do not know where to sit. Visitors (based on the argument that members would not need to be shown their places): Feine 1893, 84; Mayor 1910, 83; Ropes 1916, 191; Dibelius 1976, 134-35; Windisch 1930, 14; Laws 1980, 99-100.

"See below, $\mathbf{n} 40$.
} 
sees. $^{12}$ Others have taken the view that the scene must bear some relation to the actual experience of the addressees to be effective. ${ }^{13}$

Dibelius' scepticism about the reconstruction of the situation of the letter was a function of his classification of James as "paraenesis," by which he meant "a text which strings together admonitions of general ethical content" that addresses a specific (though perhaps fictional) audience, and to be distinguished from a mere collection of sayings (gnomologium) (Dibelius 1976, 3). Paraenesis, for Dibelius, was marked by eclecticism and a lack of topical continuity, both obstacles to discerning the author's role in forming the text. In fact Dibelius advised that the author's role should not be overestimated. ${ }^{14}$

Three-quarters of a century of work on the epistle has given reason to reassess aspects of Dibelius' view. Recent study of the letter has made a stronger case for its internal coherence and organization. ${ }^{15}$ And as Malherbe points out, even if paraenetic literature regularly included traditional and unoriginal materials, the act of selection, adaptation and application of sayings reflects both typical social settings - the conveyance of moral teaching to dependants or to members of a philosophical school, for example. $^{16}$ Moreover, as will be argued below, James 2:1-13 employs a rhetorical form which presupposes knowledge of the rhetorical situation of the addressees in the very fabric of the argument. ${ }^{17}$

12 Dibelius 1976, 125 ("this example is narrated without any concern for its reality, and hence, without any consideration of the question of the community in which, or the circumstances under which, this or even something similar could have taken place"); 129 ("this example, which is related for a paraenetic purpose, cannot be used as a historical source for actual circumstances within the Christian communities"). Similarly, Mussner 1981, 116-17; Davids 1982, 107; Hoppe 1989, 52.

13 Easton 1957, 31; Cantinat 1973, 122; Laws 1980, 98: "Yet for the example to convey his [James'] message, it must presumably bear some relation to his readers' experience, and portray a situation which either has or could obtain for them." Similarly, Schnider 1987, 57; Martin 1988, 60.

14 Dibelius 1976, 5. As late as 1989 Person $(1989,375)$ could report: "Dibelius' designation of James as 'paraenesis' ('exhortation') is universally accepted" (cf also p 376).

${ }^{15}$ Instrumental in the reassessment of James were the articles by Francis (1970) and Wuellner (1978).

${ }^{16}$ Malherbe 1992,280 n 51 . See further, Perdue 1990, 5-39.

${ }^{17}$ On the notion of rhetorical situation, see Bitzer 1968, 1-14. 
In this article, I wish to argue that the situation envisaged in James 2:1-13 involves not the abstract issue of partiality or merely the relation of rich and poor, but the more specific issue of patronage and its attendant effects on social interaction. This is a moral issue whose ramifications go to the heart of how James' communities would function as social units. It is not simply a matter of James challenging the attitude of differential treatment of persons or respect for well-born and wealthy persons. On the contrary. James rejects one of the fundamental mechanisms by which social hierarchy was articulated and the redistribution of wealth effected. To have concluded this, however, inevitably raises the question of the social-historical location of James: at which social levels and under what historical conditions would such a posture towards patronage be intelligible?

Before turning to the question of the social and historical setting of James, it is necessary to argue two preliminary points. First, that both the rhetorical genre of $2: 1-13$ and its internal texture suggests that James has in view an actual, or at least typical, occurrence. Second, that not only the exemplum in 2:2-3 coheres with a scenario of patronage, but elements from the broader literary context of the letter point in the same direction.

\section{THE RHETORIC OF JAMES 2:1-13}

In two recent independent analyses of James 2:1-13, Duane Watson and Wesley Wachob have argued, convincingly in my view, that this pericope exhibits the form of the elaboration on a theme described in Ps-Cicero's Rhetorica ad Herennium 2.18.28 (Watson 1993; Wachob 1993, 134-243). The elaboration consists of five main parts: a statement of the proposition to be argued (propositio), a brief explanation that sets forth the basis for the proposition (ratio), the proofs (confirmatio), an embellishment (exornatio) consisting of similes, examples, amplifications or previous judgments, and finally a résumé (conplexio). ${ }^{18}$

${ }^{18}$ [Cicero] Ad Herennium 2.18.282.31.50: "The most complete and perfect argument, then, is that which is comprised of five parts: the proposition (propositio), the reason (ratio), the proof of the reason (confirmatio), the embellishment (exornatio), and the résume (conplexio). Through the proposition we set forth summarily what we intend to prove. The reason, by means of a brief example subjoined, sets forth the causal basis for the proposition, establishing the truth of what we are urging. The proof of the reason corroborates, by means of additional arguments, the briefly presented reason. Embellishment we use in order to adorn and enrich the argument, after the proof has been established. The résumé is a brief conclusion, drawing together the parts of the argument" (2.18.28). See also Ad Herennium 4.43.56-44.56 and the discussion by Mack 1989, 53-57. 
James 2:1-13 conforms strikingly to this pattern. The imperative to "hold the faith of Jesus Christ without partiality" represents the proposition to be defended. This is followed by the ratio, here framed as a rhetorical question that expects an affirmative response: "for if a man with a gold ring and in fine clothing enters your assembly and a poor man also enters in shabby clothes, you regard the one who is wearing the fine clothing ..., have you not made distinctions among yourselves and become judges characterized by evil designs?" The purpose of the ratio according to Quintilian is to establish the causal basis of the proposition. Here it does so by means of the conclusion that those who engage in acts of partiality are evil judges, that is, the contrary of God. ${ }^{19}$ This establishes what in rhetorical theory is called the stasis, that is, the fundamental issue that underlies a particular case. The assertion that the addressees act as evil judges suggests that the stasis involves considerations both of what is just and what is honourable. $^{20}$ In fact the argument in verses 5-11 first treats issues of honour and then that of legality. ${ }^{21}$

The proof (confirmatio) begins in vers 5 with three rhetorical questions, each anticipating an affirmative response and each designed to expose the folly of favoring the rich. The first and third arguments concem "the honourable" and hence respond to the issue of honour raised in the ratio (Wachob 1993, 192); the second invokes another deliberative topic, "the practicable." The first question (vv 5-6a) represents an argument from the contrary: it invokes God's choice in making the poor rich "in faith" and having

19 Although Leviticus 19:18 will be cited in 2:8, the admonition against partiality (2:1) in regard to the poor

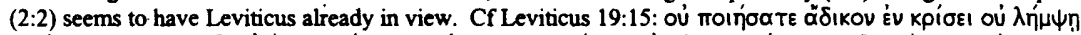

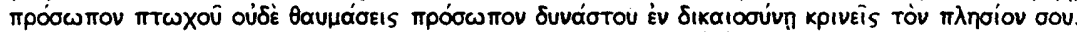

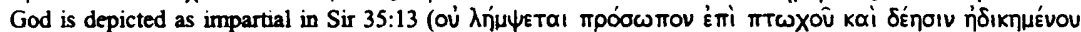

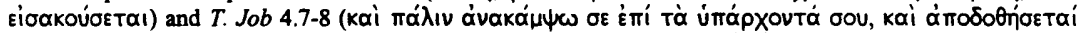

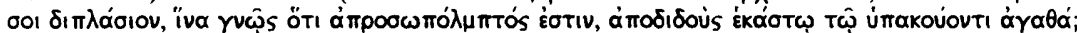

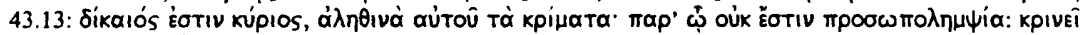

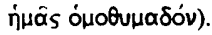

${ }^{20}$ Hermogenes (On Stases) includes under deliberative stases the topoi of what is lawful (Tò vó $\mu$ uov), just

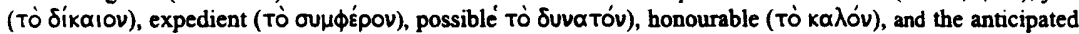

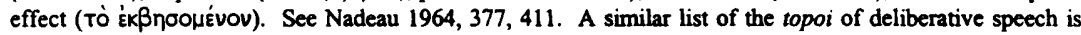
given in the Rhetorica ad Alexandrum 1.1421b.21-1422b.12.

21 The attention to what is honourable perhaps also accounts for the rather curious genitive in verse 1 , Tiv

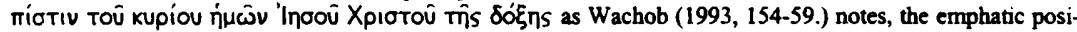
tion of $\pi \hat{\top} S \delta \delta^{\prime} \eta \bar{s}$ in the sentence prepares for the fact that the argument will in part concern conflicts in the display of honour. 
installed them as heirs of the kingdom. Since this act of installation associates the poor with the honour of the divine king, it creates a blatant contrast with the behaviour of the addressees (Uน second question ( $v 6 \mathrm{~b}$ ) recalls the topos from the Hebrew Bible of the rich oppressing the poor, ${ }^{22}$ but in doing so shifts from the aorist to the present tense, thereby drawing attention to the current practices of the rich. The appeal, in rhetorical terms, is to what is

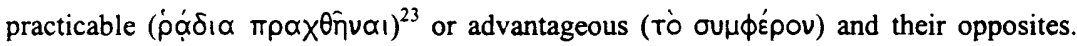
The positioning of verse $6 \mathrm{~b}$ after verses $5-6 \mathrm{a}$, coupled with the shift in tenses, has the effect of situating the current oppression by the rich between God's past choice

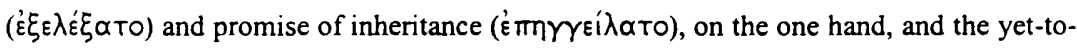
be-realized effects of that promise on the other. This juxtaposition draws attention to the impracticability of the addressees' behaviour, which collides with the obvious trajectory implicit in God's choices and promises. The final rhetorical question (v 7) returns to the topic of honour and dishonour by adducing the dishonouring of an "honourable name"

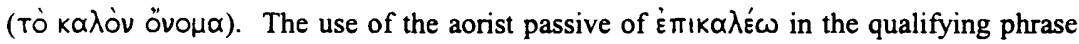
(Tò $\dot{\varepsilon} \pi I K \lambda \eta \theta \dot{\varepsilon} \nu \dot{\varepsilon} \phi^{\prime} \dot{u} \mu \hat{\alpha} s$ ) indicates that God is the source of the new name. ${ }^{24}$ Thus it is God's honour that is affronted in the act of blasphemy.

At this point the proof shifts to an argument from written law. ${ }^{25}$ The author takes as his point of departure a claim to which his audience would evidently assent, namely,

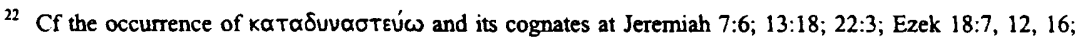
22:7, 29; Amos 4:1; 8:4; Micah 2:2; Zechariah 7:10; Malachi 3:5; Wis 2:10.

\section{${ }^{23}$ Rhetorica ad Alexandrum 1.1421b.26.}

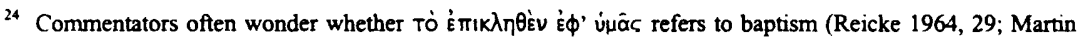
$1988,67)$. More basically, however, the phrase connotes the act of being given a surname (LSJ 635b) and occurs several times in the LXX in reference to God adopting or taking possession of persons (or Israel): Genesis 48:16; Deuteronomy 28:10; Isaiah 63:19; Amos 9:12; Bar 2:15; 5:4. In Daniel 5:12; 10:1 the construction is used of giving a nickname or by-name.

25 Watson $(1993,105)$ treats verses 8-11 as the embellishment (exomatio), evidently on the strength of [Cicero] Rhetorica ad Herennium 2.29.46, which states that the embellishment "consists of similes, examples, amplifications, previous judgments (rebus iudicatis) and other means which serve to expand and enrich the argument ..." Wachob (1993, 144, 197-223) considers it to be a second part of the proof, divided into four parts (v 8: a Proposition based on written law; verse 9: Argument from the contrary; verse 10: Rationale for Judgment based on the Law; verse 11: Confirmation of the Rational, using written testimony). 
that they live in accord with the "Royal Law," cus 19:18. The selection of this text is appropriate, not only because it had achieved the status of a summary of the Law in some sectors of second Temple Judaism and in the Jesus tradition ${ }^{27}$ but, more pertinently, because the context of Leviticus 19 contains a di-

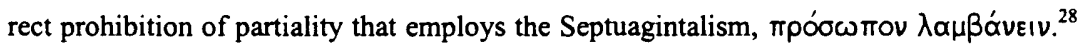
With the assistance of a Stoic maxim $(2: 10),{ }^{29} \mathrm{James}$ is able to argue that the violation of one law (partiality) makes one liable for the entire law. This latter point is then confirmed by reference to the person of the Lawgiver: the unity of the Law is guaranteed by the unity of the Lawgiver.

Even though the argument has shifted to legal matters, honour is still part of the appeal, as is clear in the conclusion of $2: 8$, "if you fulfil the royal law ... you are acting

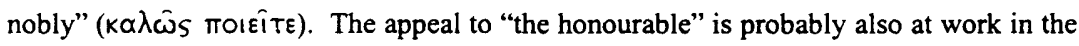
description of the law as "the royal [I e, the King's] law" and in the personalization of the argument in verse 11; for James here treats obedience to the Law as a matter of personal allegiance to a superior. Faithful execution of the superior's commands brings honour, while equivocal allegiance is dishonourable.

The conclusion (conplexio) to the argument is found in verses 12-13. The function of the conplexio was twofold: to recapitulate the argument and to make a final appeal to the emotions. ${ }^{30}$ Wachob points out that the reference to speaking and acting in verse 12 recalls the fact that $\pi \rho \circ 0 \omega \pi \circ \lambda \eta \mu \psi i \alpha$ in verses $1-4$ entails both $(1993,225)$. The mention of the coming judgment and, in particular, the designation of the law as the

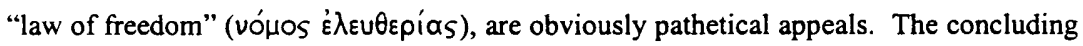

\footnotetext{
${ }^{26}$ Commentators are divided as to whether "the Royal Law" refers only to Lev 19:18 (Mussner 1981, 124; Laws 1980, 108-9; Martin 1988, 67) or to the entire Torah (Dibelius 1976, 142-44; Ropes 1916, 198; Davids 1982, 114; Wachob 1993, 200; Johnson, 1995, 230).

${ }^{27}$ On the use of Leviticus 19:18 as a summary of the Law, see Berger 1972, 99-136; Kloppenborg 1995, 98, $102-4$ and the literature cited there.

${ }^{28}$ See above $\mathrm{n} 19$.

29 Boyle 1985, 611-17, citing Augustine, Epistulae 167 (MPL 33:733-42); Seneca, De beneficiis 5.15 .1 (qui unum autem habet vitium, omnia habet); (f 4.27.1.
}

30 [Cicero], Rhetorica ad Herennium 2.30.47; Rhetorica ad Alexandrum 36.1443b-1445a; Cicero, De inventione 1.52.98; Lausberg 1960, $\S 431-42$. 
aphorism continues in the same vein, threatening merciless judgment but invoking the superiority of mercy. ${ }^{31}$

Several features of the architecture of the argument deserve comment. Watson treats the scene as an exemplum or paradeigma, citing Quintilian's discussion of the use of exempla in proofs. Since Quintilian defines the exemplum as "some past action, real or assumed, which may serve to persuade the audience of the truth of the point which we are trying to make," 32 Watson expresses some doubt as to whether James drew the example from what he knew or assumed to be the experience of his addressees. ${ }^{33}$ It is true that fabricated exempla (and myths) might be used in the confirmatio - which is what is under discussion in this section of Quintilian. In such a case the persuasiveness of the exemplum rests on the degree of correspondence between the exemplum and case under consideration, that is, on an analogical argument. In James 2, however, the exemplum occurs not in the confirmatio, but in the ratio, where it supplies the causal basis for what follows.

The appropriate construction of the ratio was of great concern, since a defective ratio inevitably rendered the entire argument defective. Ps-Cicero discusses several defective rationes: for example, one that merely restates the propositio, or one that is not universally true or one that can apply equally to an entirely different proposition. A more serious defect is a ratio that can simply be rejected by the audience on the grounds that it rests on a false supposition. ${ }^{34}$ In James the example (vv 2-3) is employed not only as the

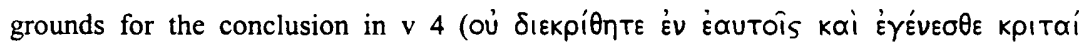

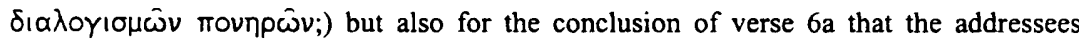

${ }^{31}$ Wachob $(1993,226)$ observes the use of asyndeton in verse 13 , noting that asyndeton is recommended by Aristotle (Rhet 3.19.6) as "most appropriate" in the conclusio. One should add Cicero, De partitione 15.53, who advises the use of asyndeton in the peroration "so as to make [the words] seem more numerous." The topes of mercy is a commonplace in the conclusio, especially of forensic speeches ([Cicero], Rhetorica ad Herennium 2.31.50).

${ }^{32}$ Quintilian 5.11.6 (emphasis added); similarly, Rhetorica ad Alexandrum 8.1429a.21-1430a.14; Cicero, De inventione, 1.30.49.

33 Watson 1993, 120: "Examples are often what could happen according to reasonable expectation ... and, when used in comparson, were often not historical." He notes, however: "since examples are to be akin to the case and portray what might reasonably be expected, we are on firm ground in inferring that partiality is exhibited by the audience."

${ }^{34}$ Cicero], Rhetorica ad Herennium 2.23.352.24.37. 
have dishonoured the poor. ${ }^{35}$ It is still in view in verses $8-9$ when the argument shifts to a proof from Torah. ${ }^{36}$ If indeed the scene in verses 2-3 were purely fictitious, the entire argument would be defective; the addressee would merely reply, "The arguments are moot, since the original supposition is false." The arguments of verses 5-8 are effective precisely because of the contrasts between God's past and future actions and the addressees' present actions, and between God's honour and their efforts to accord honours.

A second observation concerns the key term $\pi p \circ 0 \omega \pi 0 \lambda \eta \mu \psi i \alpha$. While this is usually rendered "partiality," the abstract quality of the English term disguises its rather specific connotations. Although the word is unattested before Paul (and may be Paul's coinage), it derives from the Hebrew idioms (to lift the face) and נכר פני (to regard the face). The term is regularly employed in contexts having to do with the favoring of persons of wealth and status over the poor ${ }^{37}$ and appears in conjunction with the warning of judges not to take bribes. ${ }^{38}$ The term $\pi \rho \circ 0 \omega \pi \circ \lambda \eta \mu \psi i \alpha$, of course, figures importantly in Paul's argument in Romans 2:11 where, as Bassler has shown, it refers to the dissolution of the distinction between Jew and Gentile and their utter equality before God. ${ }^{39}$ In this usage, a term that more usually concerns social rank is applied metaphorically to the economy of salvation history. Elsewhere in the New Testament (Eph 6:9; Col 3:25; James) and in Polycarp (ad Phil. 6.1), the term retains the basic nuance of deference to persons of high rank. What is clearly in view is the social fact that judicial and other social mechanisms habitually favor such persons. In warnings not to show partiality, what is at stake is not a notion of the "equality" of persons but

${ }^{35}$ Watson $(1993,105)$ in fact notes this: "Verse 6a is not an answer to the question of verse 5, but, having led the audience to affirm a basic tenet of Jewish-Christian faith that the poor (or pious) are the chosen of God,

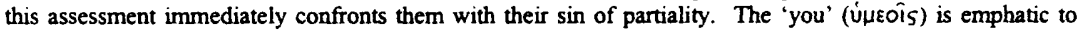
post a strong contrast between God's and the audience's treatment of the poor."

${ }^{36}$ Dibelius $(1976,142)$ notes that $\mu \varepsilon \dot{v}$ TO in verse 8 implies a strong connection with what precedes and finds the connection in verse $6 \mathrm{a}$. Curiously, he concludes that even in verse 5 the example of $2-4$ is "out of the picture" because verses $5-8$ no longer concern merely the disiribution of seats but partiality of any sort. "At most, the opening words of verse 6 might be reminiscent of the individual case in verses $2-4$, but even in verse 6 the words can be interpreted in a generalizing sense" (ibid, 137).

${ }^{37}$ Leviticus 19:15; Ps 81:2; Sir 4:27; 35:13.

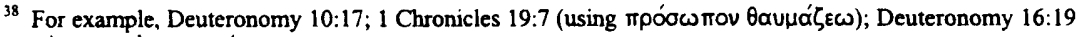

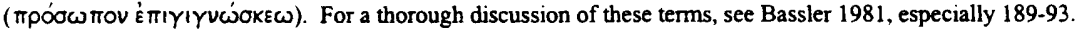

${ }^{39}$ Bassler 1981, 121-70, 186-88. 
rather a claim that God does not favor the wealthy and well-born and, therefore, human institutions should likewise resist that sort of favoritism.

This helps to make sense of another point in the argument of James, namely, the juxtaposition of an admonition against partiality with the assertion that God has chosen the poor rather than the rich to inherit the kingdom. This seemingly blatant expression of partiality on God's part ceases to be so once "impartiality" is understood as an explicit effort to challenge and negate prevailing arrangements of power and status.

In this connection, it is worth noting the suggestion of Judge, Reicke and Laws,

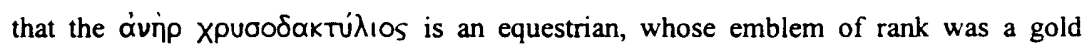
ring. ${ }^{40}$ To this it is routinely objected that other persons wore gold rings. ${ }^{41}$ But the objection misses what it at stake: whether or not James has an equestrian in mind, the mention of the ring and the $\dot{\varepsilon} \sigma \theta \tilde{n} \tau \alpha \lambda \alpha \mu \pi \rho \alpha$ - the term Polybios uses as an equivalent to the toga candida (10.5.1) - connotes the exhibiting of superior status. The description of the rich man is designed to underscore not just his wealth, but his rank.

What was the purpose of such displays and in what contexts did they occur? When Hellenistic moralists and satirists describe similar scenes involving well dressed and bejewelled men in a public assembly, they normally have to do with patrons advertising their benefactions or seeking additional clients. Lucian's Nigrinus lampoons the behaviour of the rich who "display their purple gowns and show their rings" ( $\tau \alpha$ s

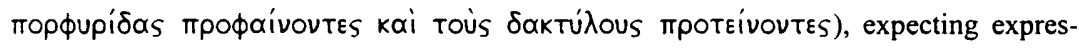
sions of thanks and acts of obeisance (Nigrinus 21). ${ }^{42}$ In Lucian's Gallus a poor cobbler Mikyllos relates a dream in which he inherited his patron's wealth: he parades in public surrounded by retainers, wears fine clothing and sixteen heavy rings, and provides a feast for his client-friends, only to have it ruined by the unexpected appearance of Pythagoras (in the form of a cock), who scatters his wealth (Gallus 12). For Lucian, both the display

\footnotetext{
40 See Cicero, In Verrem 2.3.76 (176); Suetonius, Divus Julius 33; Judge 1960, 53; Reicke 1951, 242-43; 1964, 27; Laws 1980, 98-99.

4 Davids 1982, 108. Betz $(1961,198-99)$ argues that the combination of the ring and clothing is part of a stereotyped description of the wealthy.

42 Compare also Lucian's description of the millionaire who appears in Athens, with a crowd of attendants and colorful clothing and gold jewellery (חoıki philosophers (Nigrinus 13). Lucian uses this as an illustration of the maxim that Athenians have philosophy

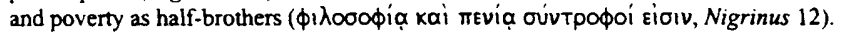


of status by the wealthy and the deference to rank shown by their toady clients are inimical to the pursuit of wisdom. Poverty and philosophy are half-brothers.

The appearance of persons of rank in their finery, either in public space or in an assembly, activated behaviour broadly classed as "flattery" and intimately associated with patron-client relations. Plutarch, for example, describes the servile behaviour of toadies who take the front seats in a theatre or the games so that they might flatter rich patrons by giving them up when the latter arrive. Others prematurely surrender the speaker's platform when a man in his purple robe and gold jewellery wanted to speak and pay rapt attention despite his inferior display of rhetoric (Quomodo adulator 58CD). The toadies that milled around persons of rank provided ample grist for the mills of moralists, satirists and writers of the New Comedy, who expounded the stereotypes of the kó $\lambda a \xi$ (flatterer)

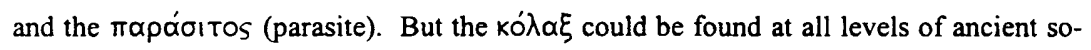
ciety, precisely because of its obdurately vertical construction. Philosophers themselves were not immune from the charge of flattery, as is shown by the criticism that Epicurus pandered to his patrons - a charge that Philodemus had to address in his treatment of frankness (parrhosia). ${ }^{43}$ Lucian of Samosata, having written an exhortation on the dangers of being a house philosopher (De mercede) and then having entered the Roman civil service in Egypt, found himself compelled to compose an apology (Apologia). In the several essays on the topic of flattery (and its opposite, parrh Osia), ${ }^{44}$ it becomes clear that it was patronage that fueled flattery and led to the servile behaviour that moralists such as Philodemus, Lucian and Plutarch found so distasteful. ${ }^{45}$

The epigraphical record makes plain that what moralists decried was practiced on a grand scale, not only by individuals, but by associations. Associations in third and second century BCE Attica regularly advertised the acts of their benefactors, unabashedly declaring that this was to encourage a rivalry among other members to act in a similar

${ }^{43}$ Criticism of Epicurus is found in Cicero, In Pisonem 28.7029.71; Diogenes Laertius 10.4-5. This criticism, according to Gargiulo (1981, 103-127, esp 105), motivated Philodemus' the contrast of the sage and the flatterer in his book on flattery.

44 On flattery, see Konstans 1996, 7-19; Momigliano 1973-1974, 2.252-63.

45 For example, Theophrastus, "Flattery" (Characters 2); Plutarch, Quomodo adulator; Philodemus, PERI

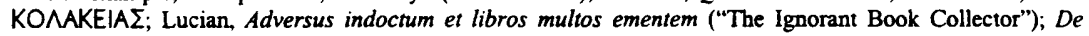
mercede conductis potentium familiaribus ("On Salaried Posts in Great Houses"). See in general, Glad 1996, 21-79, esp. 23-29. 
manner towards the gods and the membership. ${ }^{46}$ In second century CE Aemilia (Italy), a collegium of laborers and rag dealers had a bronze tablet engraved, extolling the virtues of one Tutilius Julianus, whom they sought to persuade to become their patron and whom they candidly admitted would serve as an example to other potential patrons. ${ }^{47}$ Associations were willing to lionize patrons, and the élite craved this attention, for it enhanced their status.

The well-known inscription from a second century CE Athens association of lobacchoi describes the resignation of the priest of 23 years in favor of a new priest and patron, Claudius Herodes Atticus (101-177 CE), a distinguished Athenian orator and philanthropist. ${ }^{48}$ The inscription contains an enthusiastic acclamation of Herodes Atticus and continues with a set of bylaws of the association, including regulations pertaining to the seating of members (11. 73-76) and the control of speechmaking (11. 63-67, 108-110). Throughout, the roles of the priest/patron and the vice-priest in all significant aspects of the life of the association are affirmed. What is noteworthy for our purposes is the attention to seating arrangements - both that of the former priest and the new priest/ patron in the renewed association, and that of the general membership. While it is sometimes supposed that ancient associations possessed a level of egalitarianism, in those cases where élite functioned as patrons, the language of equality masked a deeper hierarchical reality. Where one sat counted as much within the club as it did anywhere else in the ancient polis.

The scene depicted in James 2:2-3 - with its attention to seating arrangements and its deference to rank - would be recognized by James' addressees as a perfectly typical instance of the hierarchical social relationships produced by the practice of patronage. The description of the rich man and the reaction that his presence elicited mirrors the accounts of Lucian and Plutarch and the patterns of behaviour that are presupposed in the

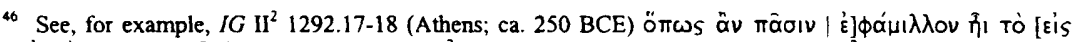

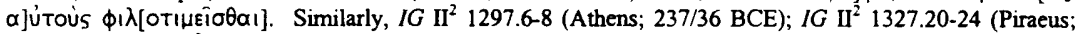
178/77 BCE); IG II $^{2}$ 1329.20-22 (Piraeus; 175/74 BCE).

${ }^{47}$ ILS 4133 = CIL LX 970 = Waltzing 1895-1900; repr. 1970, 3:479-80. On such tabulae, see Clemente 1972, $142-229$.

$48 I G \mathrm{II}^{2} 1368$ (175/76 CE; Athens) = Ziehen-Prott, LGS II 46; Michel, RIG 1564; Dittenberger, $S I G^{3} 1109$; Sokolowski, LSCG 51 .
} 
epigraphical record of private associations. To be sure, James' scene is stylized. The hypothetirel speech, inviting the poor man to sit "under my footstool," is perhaps a deliberate exaggeration. But the exaggeration is for the purpose of caricature, to set in sharpest relief actions that James finds problematic. The scene is artificial, but there is nothing fictitious about it. ${ }^{49}$

\section{THE LITERARY CONTEXT OF JAMES 2:1-13}

Several elements in the immediate context of James $2: 1-13$ suggest that patronage and its avoidance are on the horizon. First is the description of God in 1:5 as one who gives "simply" ( $\left.\dot{\alpha} \pi \lambda \hat{\omega}_{S}\right)$ and "without insult" ( $\mu$ ì óveı $\left.\delta i \zeta o v T O S\right)$. Later in the same chapter the author insists on the immutability of God as a giver of "every good and perfect gift" (1:17). These qualifications of the nature of God seem unprovoked, and while commentators have adequately traced the genealogy and connotations of the key terms, ${ }^{50}$ there has been little attempt to explain why they are introduced here. If, however, the description is taken as an anticipation of the issue of benefaction, it is possible to suggest that James is already building an argument against patrons.

One of the favorite topics of moralists and satirists was the abuse and humiliation

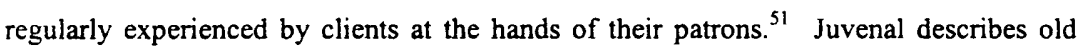

\footnotetext{
${ }^{49}$ Recently Vyhmeister $(1995,265-283)$ proposes a reading of James that assumes what is being argued here: that James is presenting a case against patronage. She concludes: "James is not so much condemning the rich and pronouncing himself in favor of the poor as he is advocating Christian respect for all, regardless of means or position."
}

so Although the Vulgate renders $\dot{\alpha} \pi \lambda \omega \bar{s}$ as affluenter (Old Latin: simpliciter), the majority of commentators are agreed that the term should be translated as "unconditionally" (Mayor 1910, 39; Martin 1988, 18), "without hesitation" (Dibelius 1976, 77-79), "vorbehaltlos, ohne Absicht, einmotivig, nicht rechnerisch" (Mussner 1981, 69), "without mental reservation" (Davids 1982, 72), or "sans arrière-pensées, sans traction,

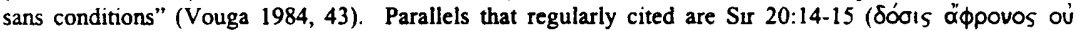

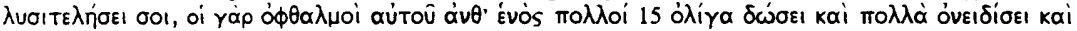

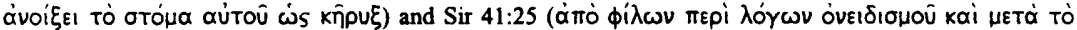

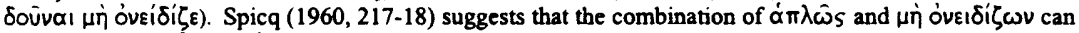

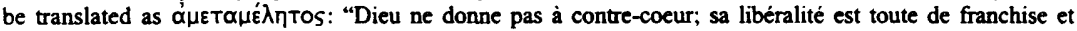
même de candeur, si l'on peut dire; de telle sorte que ses bienfaits, accordés sans réserve ni restriction aucune, sont des dons dans la plus pure acception du terme" (218).

${ }^{51}$ For example Seneca, De beneficiis 6.33.4: "Do you think that those lists, which a nomenclator can scarcely hold either in his memory or in his hand, are the list of friends. Your friends are not those who, in a long line, knock at your door, whom you distribute into two classes of those to be admitted first, and those to be second." 
clients, having dutifully come for the moming salutatio and later for a dinner, being left outside (Sat. 1.127-ر8) and ultimately cast aside after long years of "servitude" (Sat. 3.122-24). Martial reports complaints regarding the size of the sportulae distributed to clients (Epigrams 12.26.13-14; 9.100), or patrons feigning illness in order to avoid providing dinners (9.85). Satire 5 ("How Clients are Entertained") details Juvenal's efforts to dissuade Trebius, an aristocrat, from pursuing the "friendship" of Virro, a wealthy patron:

Is a dinner worth all the insults with which you have to pay for it? Is your hunger so importunate, when you might, with greater dignity, be shivering where you are and munching dirty scraps of dog's bread? First of all, be sure of this - that when bidden to dinner, you receive payment in full for all your past services. A meal is the return which your grand friendship yields you; the great man scores it against you and although it comes but seldom, he scores it against you all the same. So if after a couple of months it is his pleasure to invite his forgotten client, lest the third place on the lowest couch should be unoccupied, and he says to you, "Come dine with me," you are in seventh heaven.

This is not friendship, Juvenal insists, but humiliation and servitude. Those who subject themselves to such dinners, where they are served bad wine and food while their host dines sumptuously, might as well have their heads shaved and offer their backs to the whip (5.170-72). Lucian paints an equally dire picture of the client's life:

Far more ridiculous, however, than the rich are those who visit them and pay them court. They get up at midnight, run all about the city, let servants bolt the doors in their faces and allow themselves to be called dogs, toadies and similar names. By way of reward for this galling round of visits, they get the much-talked-of dinner, a vulgar thing, the source of many evils .... At last they go away, either finding fault or nursing a grievance, either abusing the dinner or accusing the host of insolence or neglectfulness. They fill the sidestreets, puking and fighting at the doors of brothels, and most of them go to bed by daylight and give the doctors a reason for making their rounds.

(Nigrinus 22) 
The description of God in James 1:5, 17 as one who gives unstintingly and without the slightest hint of insult or changeability is rather purposely constructed in order to collide with these stereotyped accounts of the price in humiliation that clients regularly paid for their patron's gifts. ${ }^{52}$ For James, adherence to the divine patron in fact has the effect of

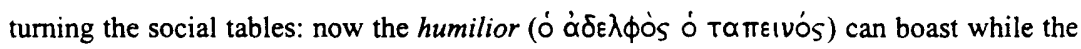
rich man must admit his low estate, as he faces the prospect of the dissolution of his wealth (1:9-10).

A second observation concerns James' restrained used of the language of friendship. James 4:4 introduces as common knowledge the maxim, $\dot{n} \phi ı \lambda i \alpha$ toú kóorou

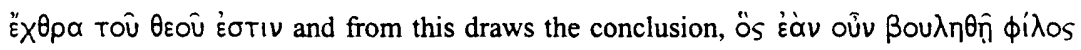

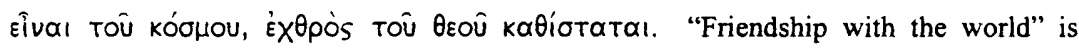
characterized in the immediately preceding verses as filled with conflict and rivalry (4:12a). It is also fundamentally unproductive: "You do not have because you do not ask; you ask and do not receive, because you ask badly" (4:2b-3). With such "friendship" James immediately juxtaposes adherence to God, who "gives grace to the humble" and exalts them (4:6-10). Again it is the language of patronage that is invoked. The humiliating, divisive, and useless nature of human patronage is contrasted with the benefits that come "from above" (3:17).

The language of friendship, indeed, was commonly used in order to mask the real nature of patron-client exchanges. As Richard Saller observes, the relative absence in Latin literature of the terms patronus and cliens was due to the invidious connotations of the terms and the rather obvious way in which they exposed social inferiority. ${ }^{53}$ Instead,

52 Similarly, Plutarch, Quomodo adulator 63F: "So, too, I imagine the gods confer their benefits, for the most part, without our knowledge, since it is their nature to take pleasure in the mere act of being gracious and doing good." This description occurs as part of a contrast of the flatterer's activities and the dubious benefits they obtain: "For any favour that evokes a reproach from its recipient is offensive, disfavorable, intolerable ...."

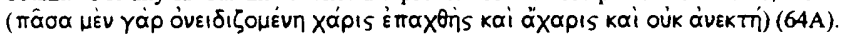

53 Saller 1982, 9; 1989. Saller notes that despite the frequent use of amicus to describe the relation between senior aristocrats and their protégés, "[t]o discuss [these] bonds . . . in terms of 'friendship' seems to me misleading, because of the egalitarian overtones that the word has in modem English. Though willing to extend the courtesy of the label amicus to some of their inferiors, the status-conscious Romans did not allow the courtesy to obscure the relative social standings of the two parties. On the contrary, amici were subdivided into categories: superiores, pares and inferiores (and then lower down the hierarchy, humble clientes). Each category called for an appropriate mode of behaviour, of which the Romans were acutely aware (Pliny, Ep. 7.3.2, 2.6.2; Seneca, Ep. 94.14)" (57). 
clientage was regularly disguised as friendship, as instanced by a letter of Fronto to the emperor Verus, in which he describes the amicitia of his protégé Gavius Clarus, who performed the work of clients and freedmen, without arrogance (insolentia) on Fronto's part or flattery (adulatio) on the part of Gavius. ${ }^{54}$ The ease with which clients could deceive themselves by thinking that they were friends with their patrons is confirmed by Juvenal's efforts (cited above) to persuade Trebius that his "grand friendship" is no more than servitude, and by the continuing pertinence of the essays by Plutarch and Maximus of Tyre on "how to tell a flatterer from a friend."

In Athens, where personal autonomy and equality were emphasized even more than in Rome, it is rare to find a citizen referring to his mpootáms; only metics, whose social inferiority was obvious, would use the term. Yet, it is also clear that the citizen class admitted of various levels of wealth and rank and that patronage was practiced. ${ }^{55}$ But as in Rome, the inequalities inherent in clientage were disguised with the term фíxo1. ${ }^{56}$

The dissembling description of patronage is not limited to urban contexts or to Athens and Rome, as recent peasant studies have shown. ${ }^{57}$ Since patron-client relations are diffuse and asymmetrical, the peasant routinely lacks the legal means by which to compel the performance of obligations. A common strategy is to cloak the unequal relationship with a language of general reciprocity, whereby the patron is said to supply goods and services as a friend or neighbor. ${ }^{58}$ This language of course further cements the bonds of loyalty of the client to the patron; but conversely it allows the client some

\footnotetext{
${ }^{54}$ Fronto, Ad Verum 2:7

ss See Gallant 1991, 143-53; Strauss 1987, 22-23.

${ }^{56}$ See Millett 1989, 15-47 and his discussion of Xenophon, Oeconomicus 2.2-10. It should not be assumed, however, that there is no meaningful distinction between friendship and clientage, as Strauss $(1987,22)$ seems to suggest. As Konstan (1995, 328-42) observes, the efforts of Juvenal, Plutarch and Seneca (among others) to distinguish genuine friendship from more instrumental relationships implies that despite the tendency to cloak clientalia as amicitia, such relationships were always vulnerable to be unmasked for what it was.
}

${ }^{57}$ Pitt-Rivers 1954, 136-59; Wolf 1977, 167-77.

58 Wolf 1977, 173; Campbell 1977, 253: "The patron says that he helps his client simply because it pleases him to help those of his friends who are in difficulties. The client explains that he is the friend of the patron, not simply because he receives benefits from him but because he is a good man." 
leverage in obtaining benefits, since in a village context, noncompliance with the obligations of friendship is shameful.

In the case of James, "friendship with the world" is characterized as fundamen-

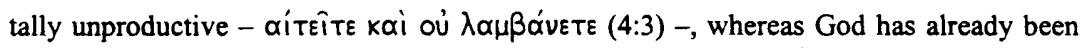
presented as generous and unstinting in his benefactions. God gives freely and God's gifts are perfect. The rhetorical strategy at work here is to demystify and expose the common language of patronage for what it is: ineffective and humiliating.

When describing the rich, James is blunt and hostile, never countenancing the cloaking of patronage with the language of friendship. James' rhetoric is intensely personal, for he knows that the relationship with a patron is not abstractly based upon wealth, but is affective, based on personal loyalty. Hence 1:11 announces not the withring of wealth, but the fading of $\dot{o} \pi \lambda$ oviolos. The rich are said to abuse the poor by dragging them to court - presumably to recover loans (2:5) - and to blaspheme their heavenly patron (2:7). They defraud day laborers of the wages to which they are entitled while they live in luxury (5:4-5), and even murder the "righteous one" $(5: 6)$. This catalogue conforms quite precisely to the principal economic exchanges between patron and client that guaranteed the peasant farmer or smallholder basic subsistence: the granting of loans for seed requirements and emergency situations, the timely payment of wages, the sharing of surpluses, and the providing of protection. ${ }^{59}$ On each point, the rich fail to live up to the moral norms of patronage, much less those of friendship.

\section{THE SOCIAL LOCATION OF JAMES 2:1-13}

To see in James 2:1-13 an argument, not merely against "partiality" conceived abstractly, but as a rather specific argument against the cultivation of patrons and, further, to see in the descriptive language that is used both of God and of the rich a concerted strategy to undermine the legitimacy of patronage, raises the larger issue of how and in what contexts such a social strategy would be effective or intelligible.

More than thirty years ago, Etienne Trocmé (1964) argued that the three topics of partiality, faith and works, and control of speech in the central section of James (2:1-

\footnotetext{
59 See Scott and Kerkvliet 1977, 147-61.
} 
3:13) were directed against the practices of post-Pauline churches, where "James" had been a visitor. That James 2:14-26 is directed against echoes of Pauline language is, of course, not new. ${ }^{60}$ Trocmé proposed that each of the three scenes in 2:13:13 concerned a liturgical problem. In James 3:1-13, the author was concemed about communities which had a large number of "teachers" (whom he judged as unqualified) and practices in which uncontrolled speaking was characteristic (cf 1 Cor 11;14). In 2:14-16, Trocmé

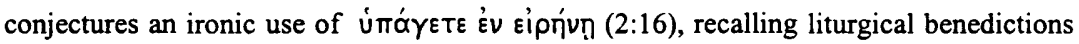
in wealthy post-Pauline churches which also countenanced or ignored economic inequalities. $^{61}$ As for James 2:1-13, Trocmé suggests that James is critical of the social practice of the Pauline churches, which, being separated from synagogues, depended upon local notables for financial support and quite naturally showed appropriate deference to such persons. Indeed, Trocmé considers the possibility that James' very use of the term

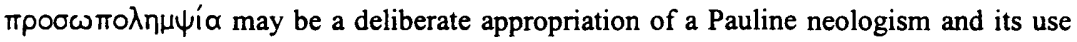
against Pauline practice (Trocmé 1964, 667).

There is much that is attractive in this thesis, in particular the way it is able to refer three diverse units of James to a common argumentative strategy. Other features of James do not fit as well, and these Trocmé sets aside, rather too quickly. In particular, he treats the woes against the rich in 5:1-6 as a "malédiction prophétique entièrement traditionnelle." ${ }^{162}$ It is quite true that some of the language of 5:1-6 can be traced to various Septuagintal texts ${ }^{63}$ and also true that the complaint that the rich have withheld

60 Kittel 1942, 71-105: James polemicizes against an "early Paulinism"; Holtzmann 1911, 2:379: James polemicizes directly against Paul; Dibelius 1976, 29-31, 174-80; Marxsen 1968, 226-31: James is directed against Pauline slogans.

${ }^{61}$ Trocmé 1964, 664-65 notes that James' treatment of faith and works (2:14-26) does not betray a direct knowledge of Galatians or Romans, and more likely represents polemic against the practice of Pauline churches about $80 \mathrm{CE}$. Any later dating of James would make it difficult to account for its lack of direct reference to Galatians and Romans.

${ }^{62}$ Trocmé 1964, 661. Trocmé treats this no differently from the example of the mirror in 1:23-24 (one of the "exemples purement rhétoriques").

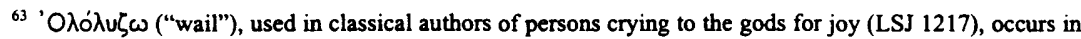
the LXX 21X in reference to disasters (Isa 10:10;13:6;14:31; 15:2, 3; 16:7 [bis]; 23:1, 6, 14; 24:11; 52:5;

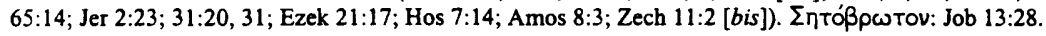


the wages of day laborers finds a striking parallel in Malachi3:5. ${ }^{64}$ On the other hand, it is not at all clear why this prophetic topos - which concerns the practice of large landowners and their (temporary agricultural workers (rather than tenants or slaves) - would be at all appropriate to the situation of urban Christians, even rich urbanites, of the Pauline sphere. ${ }^{65}$ Moreover, the argument against the rich in 2:1-13 presupposes that the rapacious behaviour detailed in 2:6-7 (which coheres with that mentioned in 5:1-6) was part of the actual or likely experience of the addressees. That lawsuits occurred in Corinth is clear from 1 Corinthians 6:1-11 and one must presume that members of the Pauline groups suffered occasionally at the hands of the courts and employers. There is no evidence, however, that this was a chronic problem in Paul's churches or that agricultural day labourers were present at all. ${ }^{66}$

A second possibility for the social location of James 2:1-13 is the same general setting as that presupposed by the moral discourses of Plutarch or Philodemus: exhortation of educated urbanites. James shares with such moralists the stereotyped descriptions of the clothing and rings of persons of rank advertising their benefactions, and moralists' criticisms of the shoddy and humiliating treatment of clients by patrons. The topics of chapter 3:1-12 (on control of speech) and 3:13-4:10 (on envy) bear some

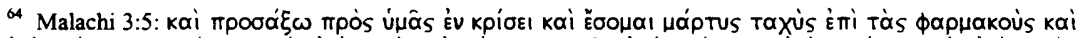

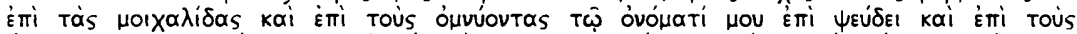

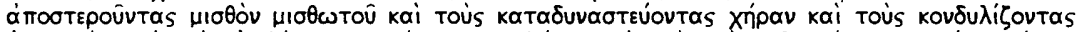

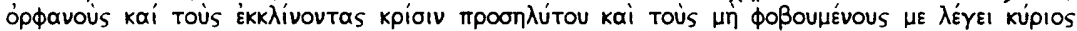

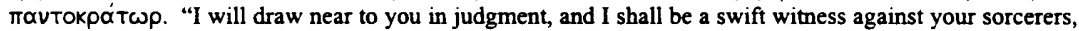
adulterers [cf James 4:4] and those who swear by my name [cf. James 5:12] for the sake of perjury and those who defraud the laborers of their wages and those who oppress [cf. James 2:6] the widow and strike the orphans and pervert judgement for the proselyte and those who do not fear me, says the Lord Panto-

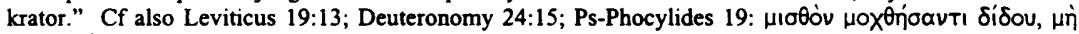
$\theta \lambda i \beta \varepsilon \varepsilon \pi \dot{v} \eta T \alpha$.

65 Some commentators have commented on the particular vivid language of James 5:1-6: Davids (1988, 3642) notes that while there is stock Septuagintal language in 5:1-6, the reference to the 'rusting' of wealth derives from the Jesus tradition, and the situation described by James corresponds to that of the peasant class in Palestine prior to the first Revolt. Similarly, Martin 1978, 97-103; Brunt 1977, 152 n 9: "The reminiscences of various prophetic books in chapter $V$ are unlikely to be merely conventional; rather they show that the greed and oppression of rich landowners denounced by Isaiah, Jeremiah, Amos, and Micah were the subject of complaint in the author's own day."
}

66 Paul in fact only uses $\pi$ TwXós to refer to the "poor of the Saints of Jerusalem (Gl 2:10; Rm 15:26), metaphorically in 2 Corinthians $6: 10$ and adjectivally in Galasians $4: 9$ of the oTOIXEi $\alpha$. The term is never used of indigent in Pauline cities. 
relationship to topics of Hellenistic moral exhortation. ${ }^{67}$ James' strategy of denying to patrons the language of instrumental friendship finds analogies in the criticism of the abuse of friendship language by Juvenal and Seneca. ${ }^{68}$

When James appeals in the conplexio to the "law of freedom" (vónos $\dot{\varepsilon} \lambda \varepsilon \cup \theta \varepsilon p\left(a_{S}\right)^{69}$ as the decisive criterion for speech and action, he introduces a familiar theme. The contrast between servitude and freedom appears with tedious regularity in discussions of patron-client relationships and the loss of freedom they entail. "To accept a favor (beneficium) is to sell one's freedom," says Publilius Syrus (61), echoing the substance of what had been expressed by many others. ${ }^{70}$ It is clear from the literature adduced by Mayor and Dibelius that the phrase employed by James here had a much wider scope than simply opposition to patronage. ${ }^{71}$ Nevertheless, in the context of an admonition to shun patronage, the audience of James would recognize the admonition to act in accord with freedom as a perfectly appropriate and conventional appeal.

On the other hand, James' argument does not develop significant topoi usual in philosophic exhortations concerning benefaction and its effects. While James is otherwise concerned with the control of speech, he says nothing on the standard topics of flattery and its opposite, frankness, even though he enjoins a communal practice of acknowledgment of faults. ${ }^{72}$ The objections, moreover, that have been raised against situating James within the context of the urban matrix of Pauline churches would apply equally here: James appears to reflect a set of social and economic concerns more closely associated with the relationship of cities, urban élites and the agricultural hinterland.

\footnotetext{
${ }^{67}$ See Johnson 1990, 329-39; 1983.

${ }^{68}$ See above, $\mathrm{n} 51$.

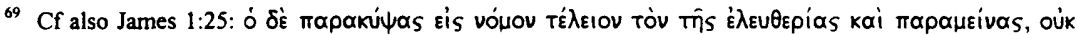

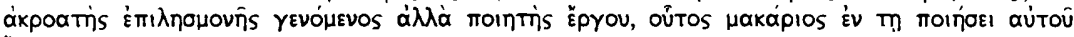
ह̋రTaı.

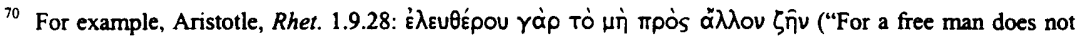
live in dependence on another"). See above, $\mathrm{n} 45$.

${ }^{71}$ Mayor 1910, 73-74; Dibelius 1976, 116-20; see also Popkes 1994, 131-42; Marucci 1995, 317-31.

72 The background of such confession is regularly (and rightly) related to a series of texts from the Hebrew Bible: Martin 1988, 210-11; Johnson 1995, 334-35.
} 
This is not to say that the critique of patronage found in the moralists is irrelevant. Resistance to patronage and the substitution of friendship for patronage can be seen much lower down on the social ladder, and it is here that we might find a better location for James' strategy. Engberg-Pedersen argues that Plutarch's essay on "How to Tell a Flatterer from a Friend" reveals a conflict that permeated ancient society between two models of interaction: one based on status-hierarchies, where the everyone sought to come out on top, or a least to avoid downward movement, and a contrasting model, based on the values of trust, sincerity, permanence and truthfulness:

\begin{abstract}
With his invocation of trust, sincerity, permanence and truthfulness Plutarch is appealing to a set of values and a way of life which was in constant danger of being done away with in ancient society, since it stood in more or less contrast to a different set of values that was so pervasive that nobody could be said to stand outside it. What I have in mind is the set of values implicit in the very strong consciousness of social and personal status that is characteristic of ancient society. Everybody had a strong sense of where he or she belonged in a status-hierarchy (no matter how we will more specifically define this) and everybody wanted so far as possible to get out on the top. Conversely, everybody was a fraid of losing status and moving down in society.
\end{abstract}

(Engberg-Pedersen 1996, 76)

The idea of friendship provided a sort of "breathing space," as Engberg-Pedersen puts it, where one could conduct relationships without risking loss of status.

Many examples can be cited of attempts to nurture a non-hierarchical social practice outside élite circles. Periclean Athens had already advanced a democratic ideal and instituted the practice of public pay as a way to break the influence of personal patrons (Millett 1989, 38-39). Obviously, this was not an option for non-élites. But at least from the period of classical Athens, and certainly extending throughout the Hellenistic period and the early Principate, the institution of small associations formed around the metaphor of pixor or a fictive family, and organized in such a way as to cultivate a sense of equality and solidarity. served as one of the possible means to escape the predatory and degrading aspects of patronage. 
From early third century Attica comes a particularly enlightening inscription containing a partial nomos of an association. ${ }^{73}$ The name of the club is missing and what remains gives no indication of which deities were honoured, although the nomos enjoins piety toward the gods and promises that those who are pious will enjoy blessings. The decree requires that members attend the funerals of deceased members and their families. Since the provision of funerals in Athens was normally a responsibility of the immediate family and, failing that, of a demarch appointed for that reason, it is likely that the association of $I G \mathrm{II}^{2} 1275$ comprised metics who could not depend upon either family relationships or the administrative functionaries of the Attic demes. ${ }^{74}$ Funerals in ancient Attica (and elsewhere) were occasions on which status was displayed, even for those who fell near the bottom of the status scale. For an association of metics to take some responsibility for funerals was to provide a mechanism by which they could mirror or mimic the honorific displays routinely accorded to citizens.

The nomos also called for members to render assistance to other members who have been wronged ( $\left.\alpha \delta 1 k \eta \hat{T} \alpha \_\right)$. The nature of such injustices and the remedies promised are left all too vague. What the association offered, however, amounted to the protection that patrons normally supplied in other associations. This offer of assistance was not expected to be kept secret; on the contrary, the inscription enjoins mutual support so that it will be known to all that "we show piety to the gods and to our friends." Elite patrons knew that their acts of benefaction and assistance would be broadcast by grateful clients and advertised on their stelai and honorific tablets. The metics of $I G \mathrm{II}^{2} 1275$ likewise knew that their treatment of fellow-members would inevitably become the subject of local gossip and took steps to ensure that this gossip would broadcast their excellent moral character.

It is noteworthy that the members refer to themselves as $\phi i \lambda o l$, "friends." In the absence of evidence of élite patrons, this designation probably does connotes a measure of equality rather than the vertical relationship of dependence typical of élite-controlled associations. The term is found also in dedicatory inscriptions to gymnasiarchs (IG VII

${ }^{73}$ IG II 1275 (Michel, RIG 1549; Sokolowski, LSCGSup 126); Tod 1906-1907, 328-38 (with a facsimile).

74 There was dramatic increase of non-citizen associations from the third century on. Some associations were comprised of foreigners gathered around a native deity $\left(I G \Pi^{2} 1261\right.$ [301/1 BCE; Aphrodite and Adonis]; 1262 [301 BCE; Tynaros, a Phrygian hero]; 1271 [297/96 BCE; Zeus Labroudos]. Others were composed at least part of slaves $\left(I G \Pi^{2} 1317 \mathrm{~b} ; S E G 24.223\right)$. 
3224; Boeotia, I CE) by members of the gymnasium (of comparable social statuses); but it also occurs among handworker associations, especially in Lydia. ${ }^{75}$ Other associations, especially in the Latin West, referred to their members as "brothers."

Conviviality and mutual assistance are at the heart of several first century Egyptian associations from Tebtunis. P. Mich. Tebt. 243 is typical of these, providing the nomos and the membership register of an association of sheep-dealers (?) from the principate of Tiberius. ${ }^{77}$ The association consisted of 16 male members, all free, some bearing Egyptian names, others Greek. The nomos calls for equal ( $\dot{\xi} \xi$ ioou) monthly contributions from each member in support of the banquets. Nowhere is there evidence of a patron.

Many of the functions of other associations are instanced here, including the communal honouring of members. The association took responsibility for funerals, requiring all to shave their heads and defile themselves. And where the Iobacchoi treated appointments to the civic cursus honourum as occasions for celebration, this association expected members who had contracted a marriage, or become fathers, or purchased land or a flock of sheep to advertise their good fortune by making special contributions to the monthly dinners. Significantly below the Iobacchoi on the social ladder and without the benefit of élite patronage, this association nonetheless provided benefits, but in the context of more egalitarian relationships.

Protection and defense figure highly in the nomos, which required members to render assistance to one another when in distress and imposed heavy fines ( 8 drackmae) on those who fail to assist. Similarly, the association agreed to stand surety for those who had been arrested as debtors up to an amount of 100 drachmae which, given the monthly dues of the association, would represent a sizable proportion of its funds.

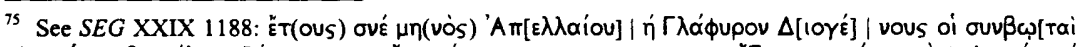

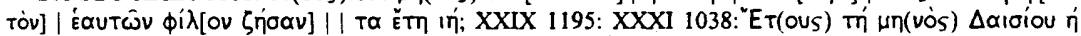

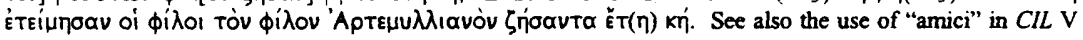
6220; X 6699; V 4395; 4483.

${ }^{76}$ CIL VI 406: fratres carissimos et collegas hon(oratos); 9128; 10681; 21812; VI 377: fratres et sorores; V 7487: fabri fratres.

7 Published by Boak 1933-1944, 1:90-100 (no. 243). See also Boak 1937, 212-20; San Nicolò 1913-1915. For the bylaws of similar associations preserved in Demotic, see Cenival 1972. 
It is obvious that associations of this sort mimicked some of the functions of groups located higher on the social ladder, even if they could not compete with the full range of benefits offered by the latter. Nonetheless, non-élite associations provided a sense of dignity and honour to members and devised mechanisms to protect them from various sorts of exploitation. Such associations as those represented by $I G \mathrm{II}^{2} 1275$ and P. Mich. Tebt. 243 provide closer analogies to the likely social level of the addressees of James and illustrate how even those at lower levels might adopt strategies either to resist patronage or to compensate for the lack of patrons.

\section{THE HISTORICAL SETTING FOR PATRONAGE AVOI- DANCE IN JAMES}

The strategies of the Attic and Egyptian associations mentioned above and the postures adopted by Hellenistic moralists represent the efforts to defend and maintain mechanisms of social support either where patronage by élites is unavailable or where other concerns make patronage unappealing. The argument of James, if the above analysis is correct, assumes either that some of the addressees have already welcomed persons of rank as patrons, or are in danger of doing so. The author seeks to undo or prevent this development of asymmetrical social relations. What we have, apparently, is just the sort of conflict that Engberg-Pedersen described: conflict between two models of interaction, one based on status-hierarchies and the other on general reciprocity. It should not be assumed, however, that resistance to patronage occurred as a matter of course. Indeed, the argument of James 2:1-13 and its resistance to patronage stands in striking contrast to way in which patronage was routinized and made quite unexceptional in most sectors of Mediterranean society.

James C Scott and Benedict Kerkvliet, on the basis of a study of patronage in southeast Asia, have argued that shifts in the way the legitimacy of patronage is perceived are less a function ideological shifts or of "rising expectations" than they are of actual shifts in economic structures and patterns of land tenure. ${ }^{78}$ Clients have an implicit notion of the balance of exchange - what they must expend in order to obtain certain

${ }^{78}$ Scott and Kerkvliet 1977, 147-161. See also Scott 1977, 21-39, especially 22. 
benefits -, and even small shifts in that balance cause a corresponding adjustment in the legitimacy of the exchange relationship.

The patron-client relationship, moreover, is not a one-way street. Clients were quite capable of manipulating patrons or playing one off against another. In the late fourth century, Libanius complained that some villagers aligned themselves with military personnel against civilian officials and tax collectors, thus depriving former patrons of revenues. The same phenomenon is documented in Palestine in the mid-third century $\mathrm{CE}^{79}$

In order to discuss the social location of James more precisely, it would be helpful to know its general geographical provenance. This is a notoriously difficult problem: locales from Jerusalem to Rome and many points in between have been advocated. ${ }^{80}$ While it is impossible to discuss the problem in detail here, I think that it is fair to say that some of the objections to a provenance in Roman Palestine - the quality of James' Greek and the use of topoi from Hellenistic moralists - are no longer persuasive given what is known now of the culture of both Judaea and the lower Galilee. ${ }^{81}$ James also adverts to a variety of natural phenomena that are well known in Palestine: the searing effects of the hamsin wind (1:11); the existence of brackish springs alongside fresh springs (3:11; e g, at Heptapegon); the cultivation of figs, olives and grapes (3:12), and the reference to the "early and late rains" (5:7). Another positive indication of a Palestinian provenance is James' use of "Gehenna" (3:6) without the need to explain the term further. ${ }^{82}$ These, of course, do not prove a Palestinian provenance, but they are also fully compatible with this.

The history of Roman Palestine, both Judaea and Galilee, affords several situations in which political and economic shifts, involving in particular shifts in landowner-

79 On Libanius, see Garnsey and Woolf 1989, 153-70, especially 162-65; Liebeschuetz 1972, 192-208; on Palestine, see Sperber 1971, 227-52.

${ }^{80}$ For a sketch of the problems, see Davids 1988, 3623-25.

81 On the use of Greek in Galilee, see Meyers 1976, 93-101; Strange 1979, 646-85, esp. 659-62; Sevenster 1968. On Judaea, see Hengel 1989, 7-18.

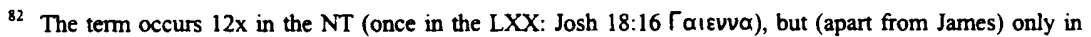
Mark (9:43 [=Mtt 5:30], 45, 47 [=Mtt 18:9]), Q (12:5) and in elaborations by Matthew $(5: 22,29 ; 23: 15,23)$. Luke uses it only once (from $Q$ ). 
ship, would have disrupted existing patterns of patronage. Some of these shifts were not, of course, peculiar to Palestine. The subversion of democratic ideals in the transition between the Republic and the Empire meant, in general, that patronage by Roman élites assumed even greater importance as a means of exerting power. ${ }^{83}$ The gradual romanization of the ruling classes resulted, as Peter Brunt has observed, in increased tension between the rulers and the ruled:

[E]ven in Judaea [he writes] upper class Jews seem mostly to have opposed the revolt, or to have sought to sabotage it, not only because (as Josephus makes king Agrippa urge) in their judgement it was certain to fail, and it was folly to 'kick against the pricks', but because Rome guaranteed the social order; the revolt of 66 was almost as much directed against native landlords and usurers as against the heathen rulers. ${ }^{84}$

Several anecdotes preserved in rabbinic literature indicate that aristocratic families in Jerusalem owned large estates in Judaea and westem Samaria and that some were implicated in land-stealing. ${ }^{85}$ In Galilee, the foundation of Tiberias by Antipas in 19/20 $\mathrm{CE}$, and especially the refoundation of Sepphoris and its elevation to the status of a city (called "Autokratoris") and "ornament of all Galilee" ${ }^{\text {" }}$ naturally entailed the resettling of persons sympathetic to Antipas along with grants of land. In the case of Sepphoris at least, this strategy was remarkably effective, both in securing an urban population which, at the first opportunity, opened its gates to Vespasian and in cementing hostile relations

\footnotetext{
${ }^{83}$ de Ste Croix 1981, 342: The subversion of most democratic institutions meant that initiative from below waned and "the new role of patronage assumed great importance, above all through the dignity and influence it brought to the patron, through his ability to recommend - and often make sure of procuring appointment to all sorts of posts that could be both honorific and lucrative."

${ }^{84}$ Brunt 1976, 165-66. Brunt further elaborates this thesis in Brunt 1977, 149-153.

${ }^{85}$ The most commonly quoted text is b. Pesa. 57a, the lament over the houses of Boethus, Hanan, Phiabi and Kathros, all wealthy priestly families. Lam. Rab. 2.5 suggests that freeholders from Bethar (near Jerusalem) were defrauded of their lands by "councilmen." On this, see Applebaum 1977, 371; Fiensy 1991, 51-55.

${ }^{80}$ Josephus, Ant. 18.27. See Smallwood 1976, 118-19.
} 
between Galilean villagers and the city. ${ }^{87}$ The (re)founding of these two cities would naturally have entailed a heightened extraction of tax revenue and corvée, expenses that would have been borne mainly by the peasant farmers. Newly imported élite, with allegiances to Antipas, would have had little reason to protect peasants in the perioicic villages from such extractions.

Other structural changes would have had no less impact. The reduction of Galilee to provincial status at the death of Agrippa I in $44 \mathrm{CE}$ would have entailed adjustments in land tenure: the holdings of loyal notables would be increased; or in the absence of such persons, new élites could be imported and supplied with land. Another significant moment was the transfer of the capital from Tiberias to Sepphoris, probably in $54 \mathrm{CE}$, when Agrippa II received Tiberias and Tarichaeae from Nero. ${ }^{88}$ This latter development further enhanced the status of Sepphoris, now the home to the official archives and the "royal tables" or bank, a loss that Tiberias bitterly resented. ${ }^{89}$

Seth Schwartz has argued that such shifts fueled the forces that eventually led to the First Revolt. Behind Josephus' often self-serving account lies a picture of Galilean society in which peasant populations had strong ties with local landowners (DUvatoi) but were antagonistic to both Tiberias and Sepphoris. The peasants were not especially well disposed to Josephus either, who sought to control the "Galileans" by alternatively allowing bandits to plunder their lands and restraining the bandits in exchange for protection money. ${ }^{90}$ The rise of brigandage, both in Judaea and the Galilee, was probably the fruit of the downward spiral caused by debt: smallholders being reduced to tenants, and then to

${ }^{87}$ Josephus, Vita 30, 38, 104, 123-24, 232, 340-48, 373-75, 394-95, 411; Bell. 2.511; 3.30-34, 59-61. Freyne (1992, 75-91) treats Tiberias and Sepphoris as "heterogenetic" cities, i.e., cities that have authority that is in conflict with old cultures and civilizations (drawing on Redfield and Singer 1954, 57-73), and explains the conflict between the "Galileans" and the élites of Tiberias and Sepphoris on this basis. Freyne (1995, 597-622) suggests that Jesus' "challenge [to] the absolute nature of kinship which can of course legitimate situations of great inequality, proposing instead an ideal of community based on love, forgiveness and shared reciprocity" should be seen in the context of the pressures created by the rise of Tiberias and Sepphoris (618).

88 This grant also included Abila and Bethsaida Julias in Peraea. Josephus, Bell. 2.252-53; Ant. 20.159; Vita 34, 38-39.

89 Although the archive in Sepphoris was untouched by the war, probably owing to Sepphoris' defensive strength and refusal to align themselves against Vespasian, a similar debt archive in Jerusalem was one of the first casualties of the revolt.

90 Schwartz 1994, 290-306. On control of brigands and their function in restraining local populations, see Shaw 1984, 5-52. 
day laborers or to bandits. ${ }^{91}$ This spiral was due in part to the creation of a large class of absentee landlords whose allegiances lay not with local communities and whose interests lay mainly in collecting rents. ${ }^{92}$ Schwartz's interest lies in accounting for the breakdown in the fabric of Galilean society that might lead to the War. Precisely the same factors absenteeism and a shift towards more exploitative economic relations - are the features which, on Scott's model, lead to resistance to patronage and to the devising of alternate means of local support.

While those scholars who would like to date James prior to the First Revolt could exploit some of these factors, it must be said immediately that the results of the failure of the Revolt produced equally, if not more, dramatic economic shifts. The ruling class of Judaea was effectively destroyed and their lands confiscated. Some who had surrendered, including Josephus, were rewarded with grants of land, but mostly away from their former estates (Josephus, Bell. 4.444). It is clear that Vespasian had already decided not to rely upon them for control of the population perhaps, as Goodman suggests, because "the ruling class had, after all, never been seen by the rest of the population as a natural elite." ${ }^{.93}$ Legio X Fretensis with a number of auxiliary units was stationed in Judaea and 800 veterans were settled at Emmaus (Bell. 7.217). We have few sources that bear on the economy of this period, but the nature of the political changes can only have meant dramatic shifts at the level of the economies of towns and villages. ${ }^{94}$ The confiscation of lands inevitably meant their reassignment to those whose loyalty was beyond question or the reduction of the lands to imperial estates. Josephus was assigned lands by Vespasian both in Judaea (Vita 425) and on the Great Plain (Vita 422), which can only mean that the formerly royal estates that existed in the Jezreel had become the personal property of Vespasian.

Judaea seems to have fared worse than the Galilee, where there is no mention of the relocation of local nobilities and no official stationing of a legionary camp until 120

\footnotetext{
${ }^{91}$ On the role of debt in the causes of the first revolt, see Goodman 1982.

92 Schwartz 1994, 303. The effects of absenteeism are also discussed by Gamsey and Woolf 1989, 158-61.

${ }^{93}$ Goodman 1987, 234. See also Goodman 1990 and, for an earlier discussion, Büchler 1912, repr. 1975, 73 106 , especially $74-86$.
}

94 Several of the rabbis of the Yavnean period were evidently persons of some wealth (which inevitably means landowners). See Büchler 1975, 90-91. 
CE, when Legio VI Ferrata was stationed at Legio (Kfar 'Otnai). ${ }^{95}$ Nevertheless, Moshe Gil has assembled data from Talmudic sources that suggest a gradual encroachment on the land of smallholders by powerful persons (both Jewish and Gentiles) called 'annasim ("men of violence") or mesiqin ( $\mu \varepsilon \sigma i T a ı)$ connected with the extraction of the annona, an oppressive agricultural tax. ${ }^{96}$ It is precisely these sorts of encroachments and the shift from cooperative to predatory economic relationships that provoke shifts in the patronal system.

It is not my interest here to suggest a precise dating of the letter of James, and indeed several settings before and after the First Revolt are possible. Rather, my concern is to propose a concrete social-historical context that might render intelligible the development of a rhetoric that opposed the nearly ubiquitous practice of patronage of non-élite by élites.

For James, this entailed three interlocking strategies. First, in 2:1-13 James in effect advises the shunning of patrons, for that is precisely the effect that his advice would have had. Few of the élite would have tolerated the cheap seats. Besides, James offers a rather frontal attack on their character, refusing to indulge the habit of confusing patronage with friendship. Second, James develops a contrasting portrait of God as the ideal of friendship: one who gives unstintingly; one who does not humiliate; and one whose gifts are always perfect. God's is an effective patronage. Third, the letter deploys a dense language of kinship - using "brother" and "sister" twenty times in a document of less than 2000 words. This usage, coupled with the appeal to friendship, represents an advocacy of general reciprocity (rather than the balanced reciprocity of patronage). It is to encourage the language of mutual obligation rather than that of status hierarchies. Together, these elements comprise an expression of resistance to patronage, and the proposing of an alternate model of social interaction and redistribution of goods. ${ }^{97}$

95 Lifshitz 1960, 109-11; Safrai 1992, 104-105. There were small imposts during the time of Eliezer ben Hyrcanus at Sepphoris and perhaps at Tiberias: $t$. Sabb. 13.9; y. Sabb. 16.15d. See also Miller 1984, 31-45.

${ }^{6}$ Gil 1970, especially 40-45; Freyne 1980, 166-70.

${ }^{97}$ I am grateful to William E Arnal, Alicia Batten, Alan J Kirk, Wesley Wachob and especially, Hami Verbin, for reading various versions of this paper and for offering helpful criticisms and advice. An earlier version of this paper was presented at the Seminar on Hebrew, Judaic, and Early Christian Studies, Faculty of Divinity, Cambridge University. I wish to thank Profs Nicholas R M de Lange and William Horbury for their kind invitation to present this paper and the members of the seminar for a helpful discussion. 


\section{Works Consulted}

Applebaum, S 1977. "Judaea as a Roman Province: The Countryside as a Political and Economic Factor." $A N R W$ II.8:355-96.

Bassler, J M 1981. Divine Impartiality: Paul and a Theological Axiom. SBLDS, vol. 59. Chico, Calif:: Scholars Press.

Berger, K 1972. Die Gesetzesauslegung Jesu; ihr historischer Hintergrund im Judentum und im Alten Testament. WMANT, vol. 40. Neukirchen-Vluyn: Neukirchener Verlag.

Betz, H D 1961. Lukian von Samosata und das Neue Testament: Religionsgeschichtliche und paränetische Parallelen. TU, vol. 76. Berlin: Akademie Verlag.

Bitzer, L F 1968. "The Rhetorical Situation.” Philosophy and Rhetoric 1:1-14.

Boak, A E R 1933-44. Papyri from Tebtunis. University of Michigan studies. Humanistic series, vols. $28,29=$ Michigan papyri, vols. 2, 5. Ann Arbor: University of Michigan Press.

— 1937. "The Organization of Gilds in Greco-roman Egypt." TAPA 68:212-20.

Boyle, Marjorie O'Rourke

— 1985. "The Stoic Paradox of James 2:10." NTS 31:611-17.

Brooten, B J 1982. Women Leaders in Ancient Synagogues: Inscriptional Evidence and Background Issues. Brown Judaic Studies, vol. 36. Chico, California: Scholars Press.

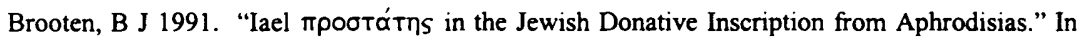
The Future of Early Christianity: Essays in Honor of Helmut Koester, ed. Birger A Pearson, 149-62. Minneapolis: Fortress Press.

Brunt, P A 1976. "The Romanization of the Local Ruling Classes in the Roman Empire." In Assimilation et résistance à la culture gréco-romaine dans le monde ancien: travaux du VIe Congrès International d'Études Classiques (Madrid, Septembre 1974), ed D M Pippidi, 161-73. Bucuresti: Editura Academiei; Paris: Société d'édition "Les Belles Lettres".

- 1977. "Josephus on Social Conflicts in Roman Judaea." Klio 59:149-53. 
Büchler, A 1912. The Economic Conditions of Judaea After the Destruction of the Second Temple. Jew's College, Publications, no. 4. London: Printed by H Hart at the University Press.

- 1975 [1912]. "The Economic Conditions of Judaea After the Destruction of the Second Temple." In Understanding the Talmud, Alan Corré, ed, 73-106. New York: Ktav.

Burchard, C 1980. "Gemeinde in der strohernen Epistel: Mutmassungen über Jakobus." In Líirche: Festschrift für Gunther Bornkamm zum 75. Geburtstag, hrsg. Georg Strecker and Dieter Lührmann, 315-28. Tübingen: J C B Mohr (Paul Siebeck).

Campbell, J K 1977. "Honour, Family and Patronage: A Study of Institutions and Moral Values in a Greek Mountain Community." In Friends, Followers, and Factions: A Reader in Political Clientelism, ed Steffen W Schmidt, James C Scott, Carl Landé, and Laura Guasti, 250-63. Berkeley: University of California Press.

Cantinat, J 1973. Les épitres de saint Jacques et de saint Jude. Sources bibliques. Paris: J Gabalda.

Cenival, F de1972. Les associations religieuses en Egypte d'après les documents démotiques. Publications de l'Institut français d'archéologie orientale du Caire. Bibliothèque d'étude, vol 46. Le Caire: Institut français d'archéologie Orientale.

Chaine, J 1927. L'Epitre de Saint Jacques. EBib. Paris: J Gabalda et Cie.

Clemente, G 1972. "Il patronato nei collegia dell'imperio romano." Studi Classici e Orientali 21:"42-229.

Cohen, S J D 1980. "Women in the Synagogues of Antiquity." Conservative Judaism 34:23-29.

Davids, P H 1982. The Epistle of James: A Commentary on the Greek Text. The New International Greek Testament Commentary. Grand Rapids, Michican: Wm. B Eerdmans.

- 1988. "The Epistle of James in Modem Discussion." $A N R W$ II.25.5:3621-45. de Ste Croix, G.E.M.

- 1981. The Class Struggle in the Ancient Greek World. London: Duckworth; Ithaca NY: Cornell University Press. 
Dibelius, M 1976. James: A Commentary on the Epistle of James. Rev Heinrich Greeven. Michael A Williams, trans. Hermeneia. Philadelphia: Fortress Press.

Easton, B S 1957. “The Epistle of James." In Interpreter's Bible, vol 12, 3-85. New York: Abingdon.

Engberg-Pedersen, T 1996. "Plutarch to Prince Philopappus on How to Tell a Flatter from a Friend." In Friendship, Flattery, and Frankness of Speech: Studies on Friendship in the New Testament World, ed John T Fitzgerald, 61-79. NovTSup, vol 82. Leiden, New York, and Köln: E J Brill.

Engelmann, H ed 1976. Die Inschriften von Kyme. Inschriften griechischer Städte aus Kleinasien, vol 5. Bonn: Rudolf Habelt.

Feine, P 1893. Der Jakobusbrief nach Lehranschauungen und Entstehungsverhältnissen. Eisenach: M Wilckens.

Fiensy, D A 1991. The Social History of Palestine in the Herodian Period: The Land is Mine. Studies in the Bible and early Christianity, vol 20. Lewiston: Edwin Mellen Press.

Francis, F O 1970. "The Form and Function of the Opening and Closing Paragraphs of James and I John." ZNW 61:110-26.

Freyne, S 1980. Galilee from Alexander the Great to Hadrian, 323 B.C.E. to 135 C.E.: A Study of Second Temple Judaism. Wilmington: Michael Glazier.

- 1992. "Urban-Rural Relations in First-century Galilee: Some Suggestions from the Literary Sources." In The Galilee in Late Antiquity, ed Lee I Levine, 75-91. New York: Jewish Theological Seminary of America.

- 1995. "Jesus and the Urban Culture of Galilee." In Texts and Contexts: Biblical Texts in Their Textual and Situational Contexts. Essays in Honor of Lars Hartman, ed. Tord Fornberg and David Hellholm, 597-622. Oslo, Copenhagen, Stockholm, and Boston: Scandanavian University Press.

Gallant, T W 1991. Risk and Survival in Ancient Greece: Reconstructing the Rural Domestic Economy. Cambridge: Polity Press.

Gargiulo, T 1981. “PHerc. 222: Filodome sull'adulazione." Cronache ercolanesi 11:103-27. 
Garnsey, P, and Woolf G 1989. "Patronage of the Rural Poor in the Roman World." In Patronage in Ancient Society, ed. Andrew Wallace-Hadrill, 153-70. London and New York: Routledge.

Gellner, E 1977. "Patrons and Clients." In Patrons and Clients in Mediterranean Societies, ed. Emest Gellner and John Waterbury, 1-6. London: Duckworth; Hanover NH.: Center for Mediterranean Studies of the American Universities.

Gil, M 1970. "Land Ownership in Palestine Under Roman Rule." RIDA 17:11-53.

Glad, C E 1996. "Frank Speech, Flattery, and Friendship in Philodemus." In Friendship, Flattery, and Frankness of Speech: Studies on Friendship in the New Testament World, ed John T Fitzgerald, 21-79. NovTSup, vol 82. Leiden, New York, and Köln: E J Brill.

Goodman, M 1982. "The First Jewish Revolt: Social Conflict and the Problem of Debt." In Essays in Honour of Yigael Yadin, ed Geza Vermes and Jacob Neusner, 417 27. Journal of Jewish Studies, vol 33. Totawa, NJ: Allanheld Osmus \& Co.

-1987. The Ruling Class of Judaea: The Origins of the Jewish Revolt Against Rome, AD 66-70. London and New York: Cambridge University Press.

- 1990. "The Origins of the Great Revolt: A Conflict of Status Criteria." In Greece and Rome in Eretz Israel: Collected Essays, ed. Aryeh Kasher, Uriel Rappaport, and Gideon Fuks, 39-53. Jerusalem: Israel Exploration Society.

Hengel, M 1989. The 'Hellenization' of Judaea in the First Century After Christ. Trans. John Bowden. Philadelphia: Trinity Press International; London: SCM Press.

Holtzmann, H J 1911. Lehrbuch der neutestamentlichen Theologie. 2. Aufl. hrsg. von Adolf Jülicher and Walter Bauer. Sammlung theologischer Lehrbücher. Freiburg im Breisgau: J.C.B. Mohr (Paul Siebeck).

Hoppe, R 1989. Jakobusbrief. Stuttgarter kleiner Kommentar. Neues Testament, NF 15. Stuttgart: Verlag Katholisches Bibelwerk.

Horsley, G H R, and John A L Lee 1994. "A Preliminary Checklist of Abbreviations of Greek Epigraphic Volumes." Epigraphica 56:129-69. 
Johnson, L T 1983. "James 3:13-4:10 and the Topos ПЕPI Ф९ONOY." NovT 25:32747.

- 1990. "Taciturnity and True Religion: James 1:26-27." In Greeks, Romans, and Christians: Essays in Honor of Abraham J Malherbe, ed David L Balch, Wayne A Meeks, and Everett Ferguson, 329-39. Minneapolis: Fortress Press.

- 1995. The Letter of James: A New Translation with Introduction and Commentary. AB, vol. 37A. Garden City, NY: Doubleday.

Judge, E A 1960. The Social Pattern of Christian Groups in the First Century: Some Prolegomena to the Study of New Testament Ideas of Social Obligation. London: Tyndale Press.

Kern, O 1900. Die Inschriften von Magnesia am Maeander. Berlin: W Spemann; repr Berlin: Walter de Gruyter, 1967.

Kittel, G 1942. “Der geschichtliche Ort des Jakobusbriefes.” ZNW 41:71-105.

Kloppenborg, J S 1995. "The Transformation of Moral Exhortation in Didache 1-5." In The Didache in Context: Essays on Its Text, History and Transmission, ed Clayton N Jefford, 88-109. NovTSup, vol 57. Leiden, New York, and Köln: E J Brill.

Kloppenborg Verbin, J S., and Bradley H McLean, eds Forthcoming Collegia, Cult Groups, and Guilds: Associations in the Ancient World.

Konstan, D 1995. "Patrons and Friends." $C P$ 90:328-42.

- 1996. "Friendship, Frankness and Flattery." In Friendship, Flattery, and Frankness of Speech: Studies on Friendship in the New Testament World, ed John T Fitzgerald, 7-19. NovTSup, vol 82. Leiden, New York, and Köln: E J Brill.

Lausberg, H 1960. Handbuch der literarischen Rhetorik: Eine Grundlegung der Literaturwissenschaft. Munich: Max Hueber Verlag.

Laws, S 1980. A Commentary on the Epistle of James. Black's New Testament commentaries. London: Adam \& Charles Black.

Liebeschuetz, J H W G 1972. Antioch: City and Imperial Administration in the Later Roman Empire. Oxford: Oxford University Press. 
Lifshitz, B 1960. "Sur la date du tranfert de la Legio VI Ferrata en Palestine." Latomus 19:109-11.

- 1967. Donateurs et fondateurs dans les synagogues juives: Répertoire des dédicaces grecques relatives à la construction et à la réfection des synagogues. Cahiers de la Revue biblique, vol 7. Paris: J Gabalda et Cie.

Mack, B L 1989. "Elaboration of the Chreia in the Hellenistic School." In Burton L Mack and Vernon K Robbins, Patterns of Persuasion in the Gospels, 31-67. Foundations \& Facets: Literary Facets. Sonoma, California: Polebridge Press.

Malherbe, A J 1992. "Hellenistic Moralists and the New Testament." ANRW II.26. $1: 267-333$.

Martin, R P 1978. "Life-setting of the Epistle of James in the Light of Jewish History." In Biblical and Near Eastern Studies: Essays in Honor of William Sanford LaSor, ed Gary A. Tuttle, 97-103. Grand Rapids: Wm B Eerdmans.

- 1988. James. Word Biblical commentary, vol 48. Waco, Texas: Word Books.

Marucci, C 1995. "Das Gesetz der Freiheit im Jakobusbrief." ZKT 117:317-31.

Marxsen, W 1968. Introduction to the New Testament: An Approach to Its Problems. Philadelphia: Fortress Press.

Maynard-Reid, P U 1987. Poverty and Wealth in James. Maryknoll, NY: Orbis Books.

Mayor, J B 1910. The Epistle of St. James: The Greek Text with Introduction, Notes and Comments. 3d ed. London: Macmillan \& Co.

Meyers, E M 1976. "Galilean Regionalism as a Factor in Historical Reconstructions." BASOR 221:93-101.

Miller, S S 1984. Studies in the History and Traditions of Sepphoris. SJLA, vol 37. Leiden: E J Brill.

Millett, P 1989. "Patronage and Its Avoidance in Classical Athens." In Patronage in Ancient Society, ed Andrew Wallace-Hadrill, 15-47. Leicester-Nottingham studies in ancient society, vol 1. London and New York: Routledge.

Mitton, C L 1966. The Epistle of James: A Commentary. Grand Rapids, Michican: Wm B Eerdmans. 
Moffatt, J 1928. The General Epistles, James, Peter, and Judas. Moffatt New Testament Commentary. London: Hodder \& Stoughton.

Momigliano, A 1973-4. "Freedom of Speech in Antiquity." In Dictionary of the History of Ideas: Studies of Selected Pivotal Ideas, ed Philip P Wiener, 2:252-63. New York: Charles Scribner's Sons.

Mussner, F 1981. Der Jakobusbrief: Auslegung. 4. Aufl. HTKNT, vol 13/1. Freiburg im Breisgau, Basel, and Wien: Herder.

Nadeau, R E., ed and trans 1964. "Hermogenes' On Stases: A Translation with an Introduction and Notes." Speech Monographs 31:361-424.

Pearson, B A 1989. "James, 1-2 Peter, Jude." In The New Testament and Its Modern Interpreters, ed Eldon Jay Epp and George W MacRae, 371-406. Bible and Its Modern Interpreters, vol 3. Philadelphia: Fortress Press; Atlanta: Scholars Press.

Perdue, L G 1990. "The Social Character of Paraenesis and Paraenetic Literature." In Paraenesis: Act and Form, ed Leo G Perdue and John G Gammie, 5-39. Semeia, vol 50. Atlanta: Scholars Press.

Pitt-Rivers, J A 1954. The People of the Sierra. London: Weidenfeld and Nicolson.

Popkes, W 1986. Adressaten, Situation und Form des Jakobusbriefes. SBS, vol 125/126. Stuttgart: Verlag Katholisches Bibelwerk.

Popkes, W 1994. "The Law of Liberty (James 1:25; 2:12)." In Festschrift Günter Wagner, 13142. International Theological Studies, Contributions of Baptist scholars, vol 1. Bern and New York: Peter Lang.

Reicke, Bo I 1951. Diakonie, Festfreude und Zelos in Verbindung mit der altchristlichen Agapenfeier. Uppsala Universitets Årskrift 1951, no 5 Uppsala: A-B Lundequistska Bokhandeln; Wiesbaden: Otto Harrassowitz.

- 1964. The Epistles of James, Peter, and Jude. AB, vol 37. Garden City, N Y: Doubleday \& Co.

Ropes, J H 1916. A Critical and Exegetical Commentary on the Epistle of St James. ICC. New York: Charles Scribner's Sons. 
Safrai, Z 1992. "The Roman Army in Galilee." In The Galilee in Late Antiquity, ed Lee I Levine, 103-14. New York: Jewish Theological Seminary of America.

Saller, R P 1982. Personal Patronage Under the Early Empire. Cambridge: Cambridge University Press.

- 1989. "Patronage and Friendship in Early Imperial Rome: Drawing the Distinction." In Patronage in Ancient Society, ed Andrew Wallace-Hadrill, 49-62. Leicester-Nottingham studies in ancient society, vol 1. London and New York: Routledge.

San Nicolò, M 1913-5. Ägyptisches Vereinswesen zur Zeit der Ptolemäer und Römer. I: Die Vereinsarten; II: Vereinswesen und Vereinsrecht. Münchener Beiträge zur Papyrusforschung und antiken Rechtsgeschichte. 2. Heft. München: $\mathrm{CH}$ Beck.

Schnider, F 1987. Der Jakobusbrief. Regensburger Neues Testament. Regensburg: Verlag Friedrich Pustet.

Schwartz, S 1994. "Josephus in Galilee: Rural Patronage and Social Breakdown." In Josephus and the History of the Greco-Roman Period: Essays in Memory of Morton Smith, ed Fausto Parente and Joseph Sievers, 290-306. SPB, vol 41. Leiden, New York, and Köln: E J Brill.

Scott, J C 1977. "Patronage or Exploitation?” In Patrons and Clients in Mediterranean Societies, ed Ernest Gellner and John Waterbury, 21-39. London: Duckworth.

Scott, J C, and Kerkvliet B J 1977. "How Traditional Rural Patrons Lose Legitimacy." In Friends, Followers, and Factions: A Reader in Political Clientelism, ed Steffen W Schmidt, James C Scott, Carl Landé, and Laura Guasti,147-61. Berkeley: University of California Press.

Sevenster, J N 1968. Do You Know Greek? How Much Greek Could the First Jewish Christians Have Known? NovTSup, vol 19. Leiden: E J Brill.

Shaw, B D 1984. "Bandits in the Roman Empire." P\&P 105:5-52.

Smallwood, E Mary 1976. The Jews Under Roman Rule from Pompey to Diocletian: A Study in Political Relations. SJLA, vol 20. Leiden: E J Brill.

Sperber, D 1971. "Patronage in Amoraic Palestine (c 220-400): Causes and Effects." JESHO 14:227-52. 
Strange, J F 1979. "Archaeology and the Religion of Judaism in Palestine." $A N R W$ II.19.1:646-85.

Strauss, B S 1987. Athens After the Peloponnesian War: Class, Faction, and Policy, 403386 BC. Ithaca, N Y: Cornell University Press.

Tod, M N 1906-7. "A Statute of an Attic Thiasos." Annual of the British School of Athens 13:328-38.

Trebilco, P R 1991. Jewish Communities in Asia Minor. SNTSMS, vol 69. Cambridge and New York: Cambridge University Press.

Trocmé, E 1964. "Les églises pauliniennes vues du dehors: Jacques 2,1 à 3,13." $S E$ 2:660-69.

Vouga, F 1984. L'Epitre de Saint Jacques. Commentaire du Nouveau Testament, Ser 2/13a. Geneve: Labor et Fides.

Vyhmeister, N J 1995. "The Rich Man in James 2: Does Ancient Patronage Illumine the Text?" AUSS 33:265-83.

Wachob, W H 1993. "The Rich in Faith and the Poor in Spirit: The Socio-Rhetorical Function of a Saying of Jesus in the Epistle of James." $\mathrm{Ph}$ D Diss, Emory University.

Waltzing, J P 1895-1900. Étude historique sur les corporations professionnelles chez les Romains depuis les origines jusqu'à la chute de l'Empire d'Occident. Mémoire couronne par l'Academie royale des Sciences, des Lettres et des Beaux-Arts de Belgique. Louvain: Uitgeverij Peeters; repr. Hildesheim: Georg Olms, 1970.

Ward, R B 1969. "Partiality in the Assembly: James 2, 2-4." HTR 62:87-97.

Watson, D F 1993. "James 2 in Light of Greco-Roman Schemes of Argumentation." NTS 39:94-121.

Weiss, B 1904. Der Jakobusbrief und die neuere Kritik. Leipzig: A Deichert (Georg Bohme).

Windisch, H 1930. Die katholischen Briefe. 2. Aufl. HNT, vol 15. Tübingen: J C B Mohr (Paul Siebeck). 
Wolf, E R 1977. "Kinship, Friendship, and Patron-Client Relations in Complex Societies." In Friends, Followers, and Factions: A Reader in Political Clientelism, ed Steffen W Schmidt, James C Scott, Carl Landé, and Laura Guasti, 167-77. Berkeley: University of California Press.

Wuellner, W 1978. "Der Jakobusbrief im Licht der Rhetorik und Textpragmatik." $L B$ 43:5-66. 